\title{
Developing Problem Based Learning Materials to Improve Student's Generic Skill in Organic Chemistry Reactions Subject
}

\author{
Ratu Evina Dibyantini ${ }^{1}$, Ramlan Silaban ${ }^{2}$, and Retno Dwi Suyanti ${ }^{3}$ \\ \{ratuevina1962@gmail.com $\}$
}

\author{
Universitas Negeri Medan, Jalan Willem Iskandar Psr. V, Medan, Sumatera Utara, Indonesia, $20221^{1}$ \\ Chemistry Education Study Program, Medan, Sumatera Utara, Indonesia, 20221 2,3
}

\begin{abstract}
This study was aimed at investigating whether the developed material could improve students' generic skill. It was a developmental research (Research and Development) conducted at chemistry department FMIPA Unimed year of 2017/2018 on students who took chemistry reaction organic subjects. The materials consisted of stereochemistry, basic concepts of organic chemistry reactions, electrophilic addition reaction, nucleophilic addition reaction, nucleophilic substitution reactions, electrophilic substitution reactions, elimination reaction and free radical reaction. The students consisted of 4 classes which were taken by using "one group pre-test post-test design" with quasi-experimental method for 2 classes, 1 class as experimental group while other as control group. The data was collected by using scoring instruments of Badan Standar Nasional Pendidikan (BSNP) which had been modified. It consisted of content feasibility, language feasibility and presentation feasibility components as well as test of 25 questions of multiple choices to measure the improvement of students' generic skills. As the implementation test, the material used was validated by the experts. The data were pre-test and post-test score of experimental and control class which were analysed by using N-gain formula by using SPSS version 20 . The result of the study showed the developed material met BSNP criteria with quite valid criteria and no revision required. Thus, it is able to improve students' generic skills.
\end{abstract}

Keywords: Research and Development, Generic Skill, Organic Chemistry Reactions

\section{Introduction}

Organic chemistry is one of the compulsory subjects in Chemistry Education Study Program, Faculty of Mathematics and Science or Fakultas Matematika dan Ilmu Pengetahuan Alam (FMIPA) Unimed. Based on the evaluation result of lecturing process, in the last there years, the average score of students' final test of organic chemistry 1 and organic chemistry 2 subjects showed that only $15 \%$ of the students got A. It indicates that many of the students were still lack of understanding the concept of organic chemistry. Thus, chemistry lecturing activity always put their efforts to improve and strengthen students' understanding concept as teacher candidates although in reality it is faced with many problems.

After the observation was conducted, some factors which interfere students in understanding organic chemistry concepts were found, namely multi-dimension of chemistry, curriculum, language, mathematical understanding, misconception and cognitive stages. In the report also stated that organic chemistry concepts are considered as difficult to understand particularly on the types of reactions, reaction mechanism, and synthesis organic (Ruchiyat,2013). Therefore, ways to improve students understanding on organic chemistry concepts and to upgrade their level of cognitive understanding are highly needed.

One of the ways to improve chemistry organic concepts mastery is by using problem based learning (PBL) model. PBL is an educational method where students develop their thinking and problem solving skills besides developing their understanding about key concepts through problem analysis in the real world (Sezgin Selcuk, Caliskan, Sahin, 2013). One of the approaches where students experience and discover the knowledge themselves is called PBL. In PBL, small group consists of 6 or 8 students with a tutor is made. The authentic and complex problem are given to help students to relate between theory and its application in reality, as well as developing their skills to overcome the complexity of reality (Tasoglu, A,K, Bakac, M, 2014). 
Another effort to improve students' learning outcomes in organic chemistry subject is by innovating learning materials. Innovation on learning materials can be developed by integrating the learning models. One of the models that can be used as an alternative is PBL. Chemistry materials which are integrated to PBL model have positive impact in teaching learning process (Sunaringtyas, 2015). Developing materials should fulfil the requirements of legal institution, namely Badan Standar Nasional Pendidikan (BSNP) dan curriculum.

Organic chemistry reactions material fits the PBL because the concepts of organic reactions can be the 'problem' in the learning stages of PBL which will develop students' generic science skills and improve their mastery on organic reactions concept.

Chemistry lecture, besides of providing students with chemistry material, it is also intended to provide them with generic science skill. Thus, university is asked to provide students with generic science skills (Anwar, Liliasari, Setiabudi, \& Martoprawiro, 2012). According to Khamsah in (Zakiyah, H., Adlim, \& Halim, A, 2014) generic science skills can be categorized into 9 indicators, they are: (1) direct observation; (2) indirect observation; (3) magnitude scale awareness; (4) symbolic language; (5) logic of obeying the principal framework; (6) logical interference; (7) law of cause and effect; (8) mathematical modeling; (9) concept construction. Dibyantini (2017) developing problem based module on alkenes and alkynes subject which could improve students' chemistry learning outcomes for 72\%. Faizah (2013), concluded that developed problems based learning materials on salt hydrolysis could improve students' soft skill and learning achievement. Silaban (2015) stated that problems based innovative material on chemistry formula and equation could improve the effectiveness of students learning in chemistry subject. This study was aimed at obtaining problem based materials which can improve students' generic science skills in organic chemistry reactions subject.

\section{Research Methodology}

This study was conducted by using "one group pre-test post-test design" with quasi-experimental method. The subject was teacher candidate students of semester 4 in chemistry education program who took organic chemistry reactions subject at the year of 2017-2018, Universitas Negeri Medan. The students were consisted of 2 classes, that of experimental class with 21 students were taught by using PBL while the control class with 27 students taught by using direct instruction model.

The data was collected by using a multiple choices test which consisted of 25 questions to measure students' generic skills which had been validated before by the expert validator. The data were pre-test and post-test score of experimental and control class which were analysed by using N-gain formula by using SPSS version 20. As the requirement in doing data analysis, normality and homogeneity test were done previously.

The procedures of this study were conducted following a research procedures that had been done by previous researcher, Sunaringtyas (2015) which consists of some stages, including: (1) designing problems based material in organic chemistry reactions subject, The materials consisted of stereochemistry, basic concepts of organic chemistry reactions, electrophilic addition reaction, nucleophilic addition reaction, nucleophilic substitution reactions, electrophilic substitution reactions, elimination reaction and free radical reaction (2) developing problems based material in organic chemistry reactions subject, (3) standardizing the developed material (4) give a trial test to the developed material.

Figure 1. The procedures of designing problems based
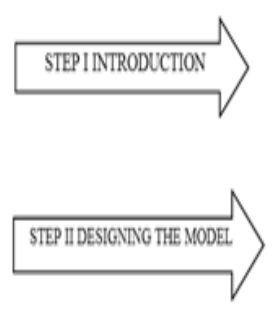
material

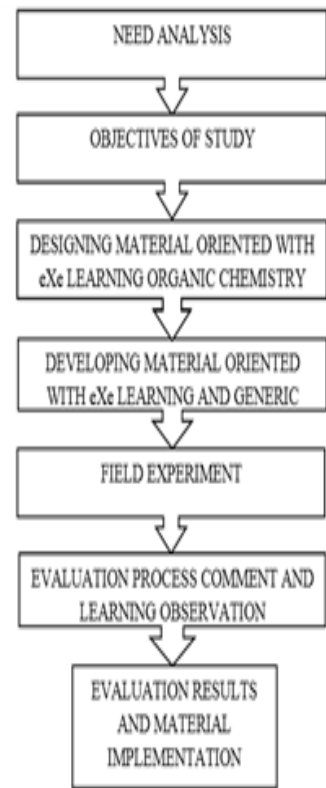


The data was collected by using scoring instruments from Badan Standar Nasional Pendidikan (BSNP) which consists of content feasibility, language feasibility and presentation feasibility components. The procedures are summarised in figure 1 .

\section{Result And Discussions \\ 3.1 Chemistry Material}

Based on the topics and sub-topics materials in organic chemistry reactions subject, the problems based chemistry materials particularly organic chemistry reactions were created. The next step was standardizing the problem based chemistry materials. The standardization was done by expert validator by using BSNP instrument which was modified to find out the results and suggestions. When the results were obtained, the developed material was revised. The data obtained were in the form of check lists $(\checkmark)$ table. The standardization was done by three experts. The overall assessment related to the validators' comments about problems based materials are shown in the following table:

Based on the content feasibility assessment on problems based material particularly organic chemistry reactions, the highest score of organization components was obtained with average score is 4.00 , it was occurred since the topic and its appropriateness to the sub-topic was organized well. Meanwhile, component with the lowest score was the content of material with 3.33. It happened because the materials as well as its contents have not yet fully been loaded. The average score from the content feasibility is 3.69 with valid criteria and no revision required.

Table 1. Validators' Assessment on Content Feasibility of the Materials

\begin{tabular}{|l|l|l|}
\hline $\begin{array}{l}\text { Elements of } \\
\text { Assessment }\end{array}$ & $\begin{array}{l}\text { The Assessed } \\
\text { Components }\end{array}$ & $\begin{array}{l}\text { Average } \\
\text { Score }\end{array}$ \\
\hline $\begin{array}{l}\text { Content } \\
\text { Feasibility }\end{array}$ & $\begin{array}{l}\text { Organization of the } \\
\text { Materials }\end{array}$ & 4,00 \\
\cline { 2 - 3 } & Scope of Material & 3,67 \\
\cline { 2 - 3 } & Validity of Concept & 3,75 \\
\cline { 2 - 3 } Capacity of Material & 3,33 \\
\hline $\begin{array}{l}\text { Total Average Score of Content } \\
\text { Feasibility }\end{array}$ & $\mathbf{3 , 6 9}$ \\
\hline
\end{tabular}

Based on the language feasibility assessment on problems based materials particularly organic chemistry reactions, the highest score was obtained by appropriateness for students' development with average score is 3.83 . It was occurred since the developed material was able to create students understanding toward organic compound reactions subject. Meanwhile, the lowest score was obtained by writing aspect component with the average score 3.50 . It happened because students' higher comprehension skills toward presented material were needed. The average score from the language feasibility components is 3.72 with valid criteria and no revision required.

Table 2. Validators' Assessment on Language Feasibility of the Materials

\begin{tabular}{|l|l|l|}
\hline $\begin{array}{l}\text { Elements of } \\
\text { Assessment }\end{array}$ & The Assessed Components & $\begin{array}{l}\text { Average } \\
\text { Score }\end{array}$ \\
\hline $\begin{array}{l}\text { Language } \\
\text { Feasibility }\end{array}$ & $\begin{array}{l}\text { Appropriateness for Students' } \\
\text { Development clarity and }\end{array}$ & 3,83 \\
\cline { 2 - 3 } & $\begin{array}{l}\text { Sentence } \\
\text { readability aspect }\end{array}$ & 3,80 \\
\cline { 2 - 3 } & Writing aspect & 3,50 \\
\cline { 2 - 3 } & Language use aspect (terms & 3,75 \\
\hline
\end{tabular}




\section{\begin{tabular}{|l|l|}
\hline Total Average Score of Language Feasibility & $\mathbf{3 , 7 2}$ \\
\hline
\end{tabular}}

Based on the presentation feasibility assessment on problems based materials particularly organic chemistry reactions, the highest score was obtained by material attractiveness component with average score was 3.83. . It was occurred since the developed material provided clear writing, attractive cover page, attractive illustrations, etc. Meanwhile, the lowest score was obtained by the material presentation aspect with average score was 3.71. It happened because index, SPU table, glossary, references and summary have not yet fully been loaded to the materials. The average score from the presentation feasibility components is 3.75 with valid criteria and no revision required.

Table 3. Validators' Assessment on Presentation Feasibility of the Materials

\begin{tabular}{|l|l|l|}
\hline $\begin{array}{l}\text { Elements } \\
\text { of } \\
\text { Assessment }\end{array}$ & The Assessed Components & $\begin{array}{l}\text { Average } \\
\text { Score }\end{array}$ \\
\hline $\begin{array}{l}\text { Presentation } \\
\text { Feasibility }\end{array}$ & Materials component & 3,72 \\
\cline { 2 - 3 } & Material attractiveness & 3,83 \\
\cline { 2 - 3 } & Material presentation aspect & 3,71 \\
\hline $\begin{array}{l}\text { Total Average Score of Presentation } \\
\text { Feasibility }\end{array}$ & $\mathbf{3 , 7 5}$ \\
\hline
\end{tabular}

The result of problems based materials on organic chemistry reactions standardizing assessment were developed based on its strengths and weaknesses analyzed to the appropriateness of some lecturers' lecturing materials. It was presented based on the feedback description related to the appropriateness of material standard. Each of the scoring description from three validators was calculated to find its average score. Then, the average score of whole scoring was also calculated to find the validators' final scores for problems based materials on organic chemistry reactions subject, those are:

Table 4. The Result of Materials Standardization

\begin{tabular}{|l|l|l|}
\hline Criteria & $\begin{array}{l}\text { Average } \\
\text { Score }\end{array}$ & Validation Criteria \\
\hline $\begin{array}{l}\text { Content } \\
\text { Feasibility }\end{array}$ & 3,69 & $\begin{array}{l}\text { Valid dan no revision } \\
\text { required }\end{array}$ \\
\hline $\begin{array}{l}\text { Language } \\
\text { Feasibility }\end{array}$ & 3,72 & $\begin{array}{l}\text { Valid dan no revision } \\
\text { required }\end{array}$ \\
\hline $\begin{array}{l}\text { Presentation } \\
\text { Feasibility }\end{array}$ & 3,75 & $\begin{array}{l}\text { Valid dan no revision } \\
\text { required }\end{array}$ \\
\hline Average Score & 3,72 & $\begin{array}{l}\text { Valid dan no } \\
\text { revision required }\end{array}$ \\
\hline
\end{tabular}

Table 4. indicates that content feasibility obtained 3,69 means valid and no revision required, for language feasibility was 3,72 means valid and no revision required, and for presentation feasibility was 3,75 means valid and no revision required. Thus, the average score obtained was 3,72 means valid and no revision required. It means that problems based materials on organic chemistry reactions was valid and no revision required. It can be concluded that the developed problems based materials on organic chemistry reactions can be used as lecturing materials. The average scores of standardization results are seen in the following figure: 


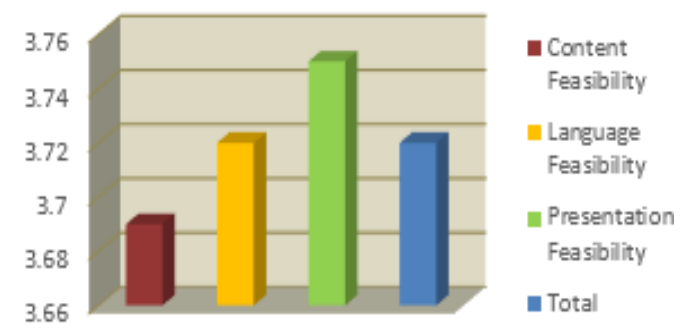

Figure 2 Materials Standardization Results

\subsection{Generic Skills}

After conducting prequisites data analysis testing, namely normality and homegenity test, the distributed normally and homogen data was obtained. Then, hypothesis testing by using SPSS program version 20 for windows can be done. The improvement of students' generic science skills is shown in Table 5 which consists of the analysis of pre-test and post-test average score. $\mathrm{N}$-gain and two sided test of significance with $95 \%$ of reliability o improve generic science skills in which the teacher candidate in experimental class was taught by using problems based materials and in control class by using no materials.

Table 5. Pre-test and post-test score of all generic science skill of science teacher candidates

\begin{tabular}{|c|c|c|c|c|}
\hline Class & $\begin{array}{c}\text { Number } \\
\text { of } \\
\text { Students }\end{array}$ & $\begin{array}{c}\text { Average } \\
\text { score of } \\
\text { Post-test }\end{array}$ & $\begin{array}{c}\text { Average } \\
\text { Score of } \\
\text { Pre-test }\end{array}$ & $\begin{array}{c}\text { N- } \\
\text { gain }\end{array}$ \\
\hline $\begin{array}{c}\text { Experime } \\
\text { nt }\end{array}$ & 21 & 87.80 & 23.62 & $\begin{array}{c}0.83 \\
840\end{array}$ \\
\hline Control & 27 & 54,67 & 20,74 & 0.42 \\
\end{tabular}

Table 5 indicates that the highest average score of post-test is 87.80 for experimental class and the lowest average score of post-test is 54.67 for control class. Meanwhile, the highest average pre-test score is 23.62 for experimental class and the lowest average score of pre-test for control class is 20.74 . . From the table, it is seen N-gain class is 0.84 which categorized as high achievement level while control class is 0.42 as medium achievement level. Therefore, it is found that problem based materials can improve generic science skill of chemistry teacher candidates. 


\section{Conclusion}

Based on the research, the development of problems based materials on organic chemistry reaction subject meets BSNP criteria. with average score of content feasibility, language feasibility and presentation feasibility was 3,72 which was categorized as valid ad no revision required. Based on the implementation of developed material, $\mathrm{N}$-gain score was 83.84 $\%$ with high achievement stage. Thus, the development of problems based materials on organic chemistry reaction subject can improve students' science generic skills.

\section{References}

[1]Anwar, M., Liliasari, Setiabudi, A., \& Martoprawiro,MA., 2012. Desain Lembaran Kerja Berbasis Pembelajaran Aktif- Kooperatife untuk Meningkatkan Ketrampilan Generik Sain Mahasiswa (Penerapan Pada Topik Mekanisme Reaksi). Jurnal Chemica, 13(1), 1-13.

[2]Dibyantini, R.E., Astuti, W., (2017), Problem-Based Module Development on Alkene and Alkyne Materials in the Senior High School, Advanced in Social Science Education and Humanities Research, $2^{\text {nd }}$ Annual International Seminar on Transformative Education and Educational Leadership, 104

[3]Faizah, S.S. Miswadi, S. Haryani., (2013), Pengembangan Perangkat Pembelajaran Berbasis Masalah untuk Meningkatkan Soft Skill dan Pemahaman Konsep, Jurnal Pendidikan IPA Indonesia, 2(2) : 120-128

[5]Ruckiyat (2013), Penerapan pembelajaran Konflik Kognitif Upaya Meningkatkan Penguasaan Konsep dan Berpikir Kritis Mahasiswa Pada Materi Reaksi-reaksi Senyawa Organik, Program Studi pendidikan IPA, UPI, Thesis, tidak diterbitkan.

[6]Selcuk, G.S., Caliskan, S., dan Sahin, M.,2013. A Comparison of Achievement in ProblemBased, Strategic and Traditional Learning Classes in Physics, International Journal on New Trends in Education and Their Implications 4 (1) : 154-164

[7]Silaban, R, dkk ( 2015), Pengembangan Bahan ajar inovatif rumus Kimia dan Persamaan Reaksi Berbasis Model Pembelajaran Problem Based Learning (PBL), Jurnal Pendidikan Kimia, 7 (1)

[8]Sunaringtyas, K., Saputro, S., dan Masykuri, M.,2015. Pengembangan Modul Kimia Berbasis Masalah Pada Materi Konsep Mol Kelas X SMA/MA Sesuai Kurikulum 2013, Jurnal Inkuiri, 4 (2) : 36-46

[9]Tasoglu, A, K, dan Bakac, M., 2014. The Effect of Problem Based Learning Approach and Conceptual Understanding and Teaching of Magnetism Topics", Eurasian Journal of Physics and Chemistry Education 6, 2, pp 110-122

[10]Zakiyah, H., Adlim., dan Abdul, H., 2014. Implementasi Model PBL pada Titrasi Asam Basa untuk Meningkatkan Kemampuan Generik Sains Mahasiswa Program Studi Pendidikan Kimia, Jurnal Pendidikan Sains Indonesia, 1 (1) : 1-16 